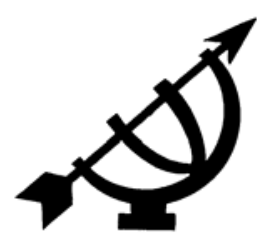

\title{
Continuing professional development for teachers in South Africa and social learning systems: conflicting conceptual frameworks of learning
}

\author{
G.M. Steyn
}

Department of Further Teacher Education

University of South Africa

PRETORIA

E-mail: steyngm1@unisa.ac.za

\begin{abstract}
Continuing professional development for teachers in South Africa and social learning systems: conflicting conceptual frameworks of learning
\end{abstract}

To transform education in this country, South African teachers need to be appropriately equipped to meet the evolving challenges and needs of the country. The national policy framework for teacher education and development is an attempt to address the need for suitably qualified teachers in South Africa. Its aim is to improve the quality of education by focusing on the professional development of teachers. This article attempts to address the following research problem: Does continuing professional development for teachers (CPDT), as stipulated by the national policy framework, have the potential to contribute to the development of teachers as proposed by social learning systems? The answer to this question has the potential to inform and influence the policy and its implementation. The answer also describes how conceptual frameworks for learning in Wenger's social learning systems conflict with effective professional development (PD) programmes and CPDT. 


\section{Opsomming}

\section{Voortgesette professionele ontwikkeling vir onderwysers in Suid-Afrika en sosiale leersisteme: konflikterende konseptuele raamwerke vir leer}

Ten einde onderwys in Suid-Afrika te verander, is dit nodig dat onderwysers toepaslik toegerus sal word om aan die uitdagings en behoeftes in die ontwikkelende land te beantwoord. Die nasionale beleidsraamwerk vir onderwysersopleiding en -ontwikkeling is 'n poging om die behoefte aan geskikte gekwalifiseerde onderwysers in Suid-Afrika te hanteer. Die doel daarvan is om die gehalte van onderwys te verbeter deur te fokus op die professionele ontwikkeling van onderwysers. Hierdie artikel poog om die volgende navorsingsprobleem te behandel: het voortgesette professionele ontwikkeling (VPOO), soos gestipuleer deur die nasionale beleidsraamwerk, die potensiaal om by te dra tot die ontwikkeling van onderwysers, soos voorgestel deur sosiale leersisteme? Die antwoord op hierdie vraag het die potensiaal om die beleid en die implementering daarvan te beïnvloed. Die vraag beskryf ook hoe die konseptuele raamwerke van leer in Wenger se sosiale leerteorie in konflik is met effektiewe professionele ontwikkelingsprogramme vir onderwysers en VPOO.

\section{Introduction}

Many reform initiatives have focused on the teacher as the key to improving learner performance (Desimone et al., 2006:178; Knight \& Wiseman, 2005:387; Mashile, 2002:174; Wanzare \& Ward, 2000:1). It is believed that

teachers have the most direct, sustained contact with students, as well as considerable control over what is taught and the climate of learning. It is reasonably assumed that improving teachers' knowledge, skills and dispositions is one of the most critical steps to improving student achievement. (King \& Newman, 2001:86.)

This explains why teachers are pressurised to be competent in their classrooms. It also justifies the urgent need for the professional development of teachers. By emphasising learning and the development of teachers, schools are able to ensure that learning processes contribute to the attainment of goals and the enhancement of quality and learner performance in schools (Browell, 2000:57; Cullen, 1999:46). 
Mundry (2005:9-12) discusses three shifts in beliefs about professional development (PD):

- The crucial value of teachers' experience and knowledge with regard to student learning is increasingly being acknowledged (Mundry, 2005:9). Even experienced teachers must continuously update their knowledge and skills, and must be involved in lifelong learning (Van Eekelen et al., 2006:408).

- PD is focused on the learning area or subject content and how it is taught. Many programmes, however, focus either on the content or on teaching techniques (Mundry, 2005:11). Unfortunately teachers often do not participate in sustained content and pedagogically-focused PD programmes (Desimone et al., 2006: 209).

- PD aims to enhance learning of challenging content by all learners. This positive change has resulted in a desire for PD programmes to more effectively equip teachers to teach challenging content and to ensure that all learners meet the required standards.

The current emphasis on professional development (PD) as an imperative for continuous improvement of teachers' skills has an inherent danger of becoming nothing more than a state-funded skills development programme in the South African context. PD should be much more than skills development or the acquisition of new knowledge of a practical nature, especially if such knowledge is acquired in a context of mandatory training, avoiding getting caught up in a technicist-functionalist paradigm. PD should rather be based on the awakening awareness of one's inability or incompetence to perform according to one's own expectations or laid-down criteria.

When the status of education in general and schooling specifically is viewed, it is evident that more than a decade of public discourse has not brought about much change, although one would like to believe that public debates are driven by serious intellectual concerns (Van Niekerk \& Killen, 2000:76). PD of teachers should not be an instrument used by the state to train teachers in the implementation of new policies but rather to improve classroom practice as a first objective. Sparks and Richardson (1997:3) even state that teachers will not change the way they teach unless they learn new ways to teach.

It is important to understand what is actually happening in schools in order to be able to address real and perceived problems with 
education. Experience as a lecturer at a university and a facilitator of PD programmes has shown clearly that many teachers do not have the ability to reflect critically on their own practice nor to try out new solutions to solve problems they encounter daily. Moreover, the efficiency of many PD programmes has been determined by the number of official workshops or the number of participants in such workshops and not by the impact of programmes in classrooms or schools. PD therefore requires an inductive, problem-centred approach (Spector, 1993:9) that relates to teachers' context. Context in this sense includes a teacher's worldview and concomitant philosophy of life that in turn will bear an influence on one's understanding of being a teacher.

South Africa requires quality teachers who are appropriately trained and developed to meet the evolving challenges and needs of the developing country (South Africa, 2007:4). According to the President's Education Initiative Research Project, the "most critical challenge for teacher education in South Africa was the limited conceptual knowledge of many teachers" (South Africa, 2007:4). Teachers' limited access to PD has also been identified as a critical area for change by The Report of the Ministerial Committee on Rural Education (2005) (South Africa, 2007:5). The national policy framework for teacher education and development is an attempt to address the need for suitably qualified teachers in South Africa (South Africa, 2007:5). The policy framework focuses on two complementary subsystems, namely, initial professional education of teachers and continuing professional development of teachers (CPDT) (South Africa, 2007:2). For the purpose of this article, the focus will be on CPDT.

Much of the research on PD has made valuable contributions to an understanding of it, but little attention has been devoted to addressing the following research question: Does continuing professional development for teachers (CPDT), as stipulated by the national policy framework, have the potential to contribute to the development of teachers as proposed by social learning systems? The answer to this question has the potential to inform and influence policy and its implementation. In order to address the research question a policy analysis on CPDT in the national policy framework was done to determine its potential to effectively develop teachers (McMillan \& Schumacher, 2006:448). A qualitative approach was deemed necessary to address the above-mentioned question. A policy analysis was done by studying various relevant documents (McMillan \& Schumacher, 2006:356, 448; Strydom \& Delport, 2005: 
315). The documents included the official national policy framework for teacher education and development, concentrating in particular on CPDT, other relevant documents on professional development of teachers, research reports on the implementation of PD programmes and Wenger's theory as reported in the literature. The research problem was approached from a pragmatic perspective since the effectiveness of the CPDT's implementation in practice is viewed as very important. The practical consequences of CPDT as proposed are vital components of both meaning and truth. All realities influence practice, in this case particularly the potential influence of CPDT is significant.

This article attempts to satisfy the objective to predict whether CPDT in the national policy framework for teacher education and development in South Africa has the potential to contribute to the professional development of teachers as proposed by social learning systems. The policy framework is a reform initiative aimed at changing the quality of teaching in South Africa, but its success cannot be guaranteed unless its potential to lead to teachers' professional development has been considered.

In order to understand learning and development in people, and in particular professionals, it is important to briefly explain Wenger's social learning theory. Instead of viewing learning as an individual process which can be separated from other activities, Wenger (1999:30) suggests that learning should rather be placed in the context of people's "lived experience of participation in the world". In contrast to the learning organisation and knowledge management, more emphasis is placed on collaborative and cooperative learning in Wenger's theory. His theory will therefore assist in evaluating the potential effectiveness of CPDT in the policy framework.

\section{Wenger's social learning theory}

Different learning theories emphasise different aspects of learning. The learning organisation, for example, focuses on developing the potential of all staff members through self-development and staff development; it also looks at the concept "learning on the job" in and through the work situation so that the organisation can develop the capacity for self-renewal and adaptation, and so that the organisation can survive and prosper (Duke, 1999:22). In addition, there seems to be a growing number of organisations which consider intellectual capital and people's knowledge as essential resources for effective organisations (Smith, 2000:236; McElroy, 2000:195; Kinnear \& Sutherland, 2000:106). The literature reveals different 
theoretical perspectives on knowledge management (Martensson, 2000:213; McAdam \& McCreedy, 1999:93). One perspective of knowledge management in particular involves theories that focus on the knowledge of people (Riley, 1998:148). The emphasis is thus on the social construction of knowledge in an organisation (Riley, 1998:148). Although the focus is on the knowledge of people, it is characterised by dialogue, action learning and problem solving.

The theory that Wenger (1999) proposes does not replace other learning theories, but rather adds another set of assumptions and its own focus. The main focus of the social learning theory is on learning as a form of active and social participation (Wenger, 1999:31). Lave and Wenger (1991:24) thus believe that learning is a way of being in the social world rather than a way of coming to know about it. As such, learning should be an integral part of people's participation in communities of practice and in organisations (Wenger, 1999:32). "Communities of practice" is a prerequisite for learning and is also at the centre of making people capable of meaningful learning (Wenger, 2000:229). Such communities of practice form when people "engage in a process of collective learning in a shared domain of human endeavor" (Wenger, 2007:1). In line with Wenger's reasoning, Lee (2005:40) believes that PD programmes designed for groups of teachers from the same school have several benefits. Teachers can share experiences, skills and problems encountered during the programme. In addition, this approach is receptive to teachers' needs and goals and how they learn; it also promotes the school's goals and has a greater impact on changing teachers' practice (Lee, 2005:46).

Wenger (2000:230) warns, however, that communities of practice should not be "romanticized", because they can also not learn to learn from their experiences. According to him there should be leadership in maintaining a spirit of learning and "pushing" the community's development (Wenger, 2000:230). Furthermore, members in the community should know each other well enough to interact productively and to identify people who may be of assistance when required (Wenger, 2000:230). As members they are involved in joint activities and discussions, assist one another and share knowledge and skills. As such they share competence between themselves. Members of a community of practice are practitioners who develop a shared practice through ways of addressing problems and sharing practices. Moreover, mutual commitment is deepened when communities of practice take responsibility for their own learning, which can develop the practice even further (Wenger, 2000:231). 
By taking part in communities of practice, staff members define what constitutes competence in the institution (Wenger, 2000:229). Socially-defined competence is an interplay of people's experiences, that is, an interplay in which learning occurs (Wenger, 2000:226). Newcomers to an institution want to learn from others, the so-called "old-timers" in the institution, and they strive to align their experiences with the competence of these people at the institution (Wenger, $2000: 227)$. The competence of "old-timers" at the institution then "pulls" the experiences of the newcomers (Lave \& Wenger, 1991: 49).

Competence may also develop when people attend conferences, training sessions or any other event which opens their "eyes to a new way of looking at the world" (Wenger, 2000:227). Professionals may identify their shortcomings through such training sessions and communicate their new-found insights with colleagues on their return to the institution. By doing this, these people try to change how the institution defines competence and they use their experience to "pull" their community's competence along (Wenger, 2000: 227).

There have been various ways to try to take charge of, to direct, to demand or to accelerate learning (Wenger, 1999:33). Such endeavours include professional development and training programmes (Wenger, 1999:33). Continuing professional development for teachers which aims at developing teachers and contributing to their learning for the sake of improved learner performance can act as a possible example. The following criteria from Wenger's theory are applied to CPDT: opportunities for collaboration and collective learning in schools; the important role of leadership and support in CPDT; the duration of CPDT programmes; and feedback to teachers.

\section{The national policy framework for teacher education and development in South Africa with special reference to continuing professional development for teachers (CPDT)}

The purpose of CPDT is to equip teachers to meet the challenges and demands of a democratic South Africa in the 21st century (South Africa, 2007:1). As such professional development (PD) programmes should emphasise the integrated development of learning area/subject content knowledge and pedagogical skills; teachers' competence in the language of teaching and learning; the 
changing social character of schools; and skills required for the teaching of diverse classrooms (South Africa, 2007:21).

The ultimate aim of CPDT is to enable learners to "learn well and equip themselves for further learning and for satisfying lives as productive citizens, for the benefit of their families, their communities and our nation" (South Africa, 2007:25). The CPDT system essentially aims to contribute towards the improvement of teachers' teaching skills by equipping teachers to effectively execute their essential and demanding tasks; to continually improve teachers' professional competence and performance to provide quality education; to enable and empower teachers by improving their professional confidence, learning area/subject knowledge and skills, and teaching and classroom management; to improve the professional status of teachers; and to assist teachers in identifying suitable PD programmes that may contribute towards their professional growth and therefore protect them from misleading providers (South Africa, 2007:1).

The policy framework identifies four types of CPDT activities: school-driven activities, employer-driven activities, qualification-driven activities, and others offered by approved organisations (South Africa, 2007:17). A distinction is also made between compulsory and other self-selected PD programmes; the former is paid for by the education authority involved, while teachers may receive bursaries for self-selected PD (South Africa, 2007:3).

All teachers registered at the South African Council for Educators (SACE) have to earn PD points by selecting approved professional development activities that meet their development needs (South Africa, 2007:20). Accumulating PD points is also an internationally acceptable technique to recognise members' continuing professional development (Desimone et al., 2006:205).

In order to understand any professional development initiative, such as CPDT, it is important to have a clear understanding of professional development (PD).

\section{An overview of professional development teacher programmes}

Significant literature on PD has emerged in the last decade. Workshops, seminars and conferences are considered to be the traditional approaches to PD (Boyle et al., 2005:4; Lee, 2005:40). These approaches had a more simplistic and technical view of teaching 
and believed that teachers' knowledge and skills could be improved by using external experts (Lee, 2005:39). These approaches are criticised for not giving teachers the time, activities and the content to improve their knowledge and skills (Birman et al., 2000:29). These approaches proved to be ineffective since they did not sufficiently change teachers' content knowledge or pedagogical skills (Mewborn \& Huberty, 2004:4). This is why Mundry (2005:14) suggests that policy makers and education managers should "abandon outmoded approaches to staff development and invest in these more 'practice-based' approaches to professional learning for teachers".

The reform types of programmes are longer and focus on content, active learning and coherence. The benefit of such PD programmes is that teachers can make links with classroom practice over an extended period of time. These longer-term PD programmes have been designed to assist teachers, through direct practical experiences, to improve student learning (Garet quoted in Lee, 2005:39).

Professional growth in teachers occurs when a PD programme acknowledges teachers' personal and professional needs (Lee, 2005: 40). It means that appropriate strategies should be used to determine in which areas a teacher is lacking skills (Lee, 2005:41). Needs-based PD is also supported by other researchers who believe that principals could evaluate and monitor teachers, choose what kinds of PD programmes teachers need and then guide them to identify programmes that fit their professional needs (Desimone et al., 2006:206).

Considering the above, it is clear that PD is most effective when it is based on teachers' needs and is a continuous process which includes formal, systematic and suitably planned development and follow-up through supportive observation and feedback, staff dialogue and peer coaching (Bernauer, 2002:89; Bolam, 2003:103; Lee, 2005:47).

A crucial question that emerges is: Do recent views on PD and Wenger's social learning theory share the same concepts of learning as those promoted by CPDT in the policy framework? In other words, how useful is Wenger's social learning theory for the enhancing of an understanding of CPDT? 


\section{Professional development, Wenger's social learning system theory and continuing professional development for teachers: conflicting conceptual frameworks of learning}

Although CPDT in the national framework expects teachers "to take charge of their self-development by identifying the areas in which they need to grow professionally" (South Africa, 2007:3), it does not explicitly explain the important role of schools as communities of practice (as advocated by Wenger's theory) in identifying such needs. The emphasis in particular is on an individual's development which in essence contradicts the learning theory of Wenger. He advocates communities of practice which are the "social containers" of competence and also the basic building block of a social learning system (Wenger, 2000:229). Communities of practice form when people "engage in a process of collective learning in a shared domain of human endeavor" (Wenger 2007:1). Furthermore, collective learning is required where the acquired knowledge and skills are shared with colleagues through joint activities and discussions (Wenger, 2007:2). Bodies responsible for accrediting CPDT programmes need to be wary of models that have a "one-size-fits-all" approach. Approved programmes should be differentiated to meet the learning needs and learning styles of all teachers, but more importantly to encourage collective learning in communities of practice. Lave and Wenger (1991:50) succinctly support this view: "In contrast with learning as internalization, learning as increasing participation in communities of practice concerns the whole person acting in the world." It remains the responsibility of each staff member, however, to continually experiment, deliberately reflect on what has happened as a result of the individual and team effort, and to reflect with others on the action of the whole system in order to learn how to improve practice (Boyle et al., 2005:5; Dymoke \& Harrison, 2006:78).

Effective PD programmes require the isolation that permeates teaching to be broken down so that teachers can work together as professionals and assist in the development of the school (Bezzina, 2002:77; Collinson, 2001:267). This collaboration will contribute towards the development of a positive school culture that is committed to change and the creation of better learning opportunities for all (Robinson \& Carrington, 2002:240; Rhodes \& Houghton-Hill, 2000: 431). CPDT does not explicitly acknowledge the importance of collaborative learning among staff members in sustaining the PD of staff, since it focuses on the development of individual teachers. As 
such, CPDT neglects to show the importance of teacher collaboration and a more collegial culture in schools.

In collaborating schools, teachers are actively engaged in complementing and developing each others' knowledge and skills, which provides ample opportunities for teachers to work together and learn from each other. Collaboration among teachers utilises their strengths, knowledge and skills, while also stimulating reflection and broadening perspectives - this gives rise to more effective teaching and ownership of their professional learning (Dymoke \& Harrison, 2006:80; Boyle et al., 2005:4; Lee, 2005:40; Blackmore, 2000:3). Collaborative learning is also regarded as the key to sustaining momentum (Anon., 2003:21). Wenger (2000:229) concisely supports this view by stating that communities of practice are a prerequisite for learning. Furthermore, although there are intrinsic rewards in becoming skilled, the value of participation to the community and the learner lies in becoming part of the community - the sense of belonging. Moving towards full participation involves greater commitment of time, intensified effort and more responsibility within the community with more difficult tasks and an increasing sense of identity as a master practitioner (Lave \& Wenger, 1991: 111). Although Wenger's theory acknowledges the development of an individual's competence, as is the case with the accumulation of points in the CPDT, the emphasis in the learning theory is on collective learning in schools. As such, the approach in the policy framework almost supports the traditional culture of teacher isolation by having individual teachers earning PD points. This may have a negative impact on the culture and performance of the school.

Although a principle in the policy framework refers to "sustained leadership and support" for quality education (South Africa, 2007:3) and CPDT acknowledges school-led programmes for teachers' development (South Africa, 2007:18), the active involvement of school managers in CPDT is not explicitly encouraged or explained. This concern is supported by Wenger (2000:223) who believes that leadership plays a key role in maintaining a spirit of learning and pushing the community's development (Wenger, 2000:230). Successful leaders provide the necessary infrastructure for communities of practice to thrive (Wenger, 2001:41). Principals can, therefore, play a key role in CPDT by identifying teachers' needs, motivating and supporting their development, and working towards a collaborative school culture with shared values and norms. Site-based PD programmes as communities of practice are generally successful when principals play a key role in effectively implementing and 
sustaining teachers' learning and growth. Principals provide intellectual stimulation when they challenge teachers to re-examine their assumptions about their teaching practices and rethink how they could be more effective (Yu et al., 2000:370).

Table 1 presents a summary of the relationship between components of PD and the impact on work performance of teachers (Rhodes \& Houghton-Hill, 2000:432). Without putting theory into practice, any PD is limited to the level of the superficial. It is interesting to note that high transfer of knowledge and skills is only achieved when coaching is added to the equation (Rhodes \& Houghton-Hill, 2000:431). A barrier here is the lack of teacher collaboration and support from school leaders and other colleagues in realising the impact in the classroom (Anon., 2001/2002:18; Brandt, 2003:10). Wenger's theory on the need for communities of practice to improve performance of professionals is once again supported. Furthermore, it supports Lave and Wenger's (1991:57) belief that learning should never be viewed as a simple process of transfer or assimilation. Collaborative learning among staff members is, unfortunately, not explicitly acknowledged by CPDT, nor is it rewarded.

Table 1: The relationship between components of training and impact on educators' performance

\begin{tabular}{|l|lll|}
\hline \multirow{2}{*}{$\begin{array}{l}\text { Training components and com- } \\
\text { binations }\end{array}$} & \multicolumn{4}{|l|}{ Impact on teachers' job performance } \\
\cline { 2 - 4 } & Knowledge & Skill & Transfer \\
\hline Theory & Low & Low & Nil \\
Theory and demonstration & Medium & Medium & Nil \\
Theory, demonstration \& practice & High & Medium & Nil \\
$\begin{array}{l}\text { Theory, demonstration, practice \& } \\
\text { feedback }\end{array}$ & High & Medium & Low \\
$\begin{array}{l}\text { Theory, demonstration, practice, } \\
\text { feedback \& coaching }\end{array}$ & High & High & High \\
\hline
\end{tabular}

(Rhodes \& Houghton-Hill, 2000:432)

The duration of PD influences the depth of teacher change (Lee, 2005:39). The main model for teachers advocates long-term training programmes, but in reality one-shot programmes are still offered which often do not emphasise subject content or pedagogical skills (Desimone et al., 2006:183; Mewborn \& Huberty, 2004:59). Although CPDT will only acknowledge accredited PD programmes to stamp out ineffective PD programmes (South Africa, 2007:19), no 
mention is made of the duration, support, feedback and evaluation of such programmes. CPDT supports the expansion of teachers' content and pedagogical knowledge, which is in line with effective PD programmes. A long-term approach to CPDT that maximises staff interaction and feedback on teachers' performance is, however, not explicitly acknowledged. In the past, traditional one-shot approaches did not lead to effective PD of teachers. When approving PD programmes, SACE has to see that feedback and coaching, for example, form an integral part of the PD programmes. It is also important to select content experts with the didactical skills needed to present contextualised PD programmes. Teachers do not "tolerate" programmes that "don't work" with their learners (Mewborn \& Huberty, 2004:6).

\section{Conclusion}

CPDT is an initiative by the Department of Education to enhance the knowledge and skills of South African teachers. Its success will be determined by its impact on the quality of teaching in schools. The policy framework provides broad guidelines for the implementation of CPDT. It predominantly focuses on the professional development of individual teachers with the point-driven system introduced to be registered as professionals in the education system. This may negate the crucial influence of competence building among staff members in schools. It may therefore be risky to disregard important theories of learning such as Wenger's social learning theory when considering the potential impact of CPDT to influence teachers' learning. As such it is recommended that appropriate approaches to learning and PD of teachers should be acknowledged when implementing CPDT. These include more collaboration and interaction between teachers, continuous support to teachers in schools, more, longer-term programmes and feedback on teachers' development.

With the emphasis on an individual's professional development, the policy does not provide for measuring the impact of PD on teachers' classroom practice nor on the development of schools. It is recommended that accredited PD programmes should make provision for measuring the impact of classroom practice, increased learner performance and the influence of the PD programme on the development of the school.

Although the policy framework acknowledges school-driven activities as a type of CPDT, it does not explicitly explain the important role of schools as communities of practice in improving the quality of teaching among staff members. The question remains how schools 
can act as accredited PD providers for the development of teachers and how such teachers will receive the necessary points to be accredited by the Department of Education. Teachers who have been trained through PD may also act as competent providers in cascading the knowledge and skills to their individual schools.

In conclusion, Lee (2005:47) succinctly explains his view on effective PD:

Overall, for the best outcomes, a PDP [professional development programme] should have an appropriate level of challenge and support, provide activities demonstrating new ways to teach and learn, build internal capacity, use a team approach, provide time for reflection and evaluate the effectiveness and impact of its activities.

This also implies the need to continuously undertake school-based action research in the implementation of PD to ensure that shortcomings in practice are identified and addressed.

One of the great challenges of CPDT is to motivate teachers to become committed to their own development and learning and to participate as active members in a community of practice as advocated by Wenger's theory. The punitive measure that "teachers who do not achieve a minimum number of PD points over two successive cycles of three years will be accountable to SACE for such failure" (South Africa, 2007:20), does not seem to have the potential to be having much effect on poor performing teachers. The challenge is thus to encourage a collaborative culture in communities of practice where teachers are involved in joint activities and discussions, assist one another and share knowledge and skills so as to improve the competence of teachers in South Africa.

\section{List of references}

ANON. 2001/2002. New staff development standards issued. Reading today, 19(3):17-18.

ANON. 2003. Igniting your learning approach: how to encourage deeper learning in your organization. Development and learning in organizations, 17(2):21-23.

BERNAUER, J. 2002. Five keys to unlock continuous improvement. Kappa delta pi record, 38(2):89-92.

BEZZINA, C. 2002. Preparing a model of professional development schools in Malta. Curriculum and teaching, 17(2):73-84.

BIRMAN, B.F., DESIMONE, L., PORTER, A.C. \& GARET, M.S. 2000. Designing professional development that works. Educational leadership, 57(8):28-33. 
BLACKMORE, J. 2000. Developing conditions to teacher professional renewal. Teacher learning network, 7(1):3-5.

BOLAM, R. 2003. Professional development and professionalism. (In Bell, T. \& Bell, L., ed. The principles and practice of educational management. London: Chapman.)

BOYLE, B., LAMPRIANOU, I. \& BOYLE, T. 2005. A longitudinal study of teacher change: What makes professional development effective? Report of the second year of the study. School effectiveness and school improvement, 16(1):1-27.

BRANDT, R. 2003. Is this school a learning organization? 10 ways to tell. Journal of staff development, 24(1):10-17.

BROWELL, S. 2000. Staff development and professional education: a cooperative model. Journal of workplace learning, 12(2):57-65.

COLLINSON, V. 2001. "I don't have enough time": Teachers' interpretations of time as a key to learning and school change. Journal of educational administration, 39(3):266-281.

CULLEN, J. 1999. Socially constructed learning: a commentary on the concept of the learning organisation. The learning organization, 6(1):45-52.

DESIMONE, L.M., SMITH, T.M. \& UENO, K. 2006. Are teachers who sustained, content-focused professional development getting it? An administrator's dilemma. Educational administration quarterly, 42(2):178-215.

DUKE, C. 1999. Lifelong learning: implications for the university of the 21st century. Higher education management, 11(1):19-35.

DYMOKE, S. \& HARRISON, J.K. 2006. Professional development and the beginning teacher: issues of teacher autonomy and institutional conformity in the performance review process. Journal of education for teaching, 32(1):71-92.

KING, M.B. \& NEWMAN, F.M. 2001. Building school capacity through professional development: conceptual and empirical considerations. The international journal of educational management, 15(2):86-94.

KINNEAR, L. \& SUTHERLAND, M. 2000. Determinants of organisational commitment amongst knowledge workers. South African journal of business management, 31(3):106-112.

KNIGHT, S.L. \& WISEMAN, D.L. 2005. Professional development for teachers of diverse students: a summary of the research. Journal of education for students placed at risk, 10(4):387-405.

LAVE, J. \& WENGER, E. 1991. Situated learning: legitimate peripheral participation. Cambridge: Cambridge University Press.

LEE, H.L. 2005. Developing a professional development programme model based on teachers' needs. The professional educator, 27(1 \& 2):39-49.

MARTENSSON, M. 2000. A critical review of knowledge management as a tool. Journal of knowledge management, 4(3):204-216.

MASHILE, E. 2002. Continuous professional development for educators: the state, professional councils and higher education. South African journal of higher education, 16(1):174-182.

MCADAM, R. \& MCGREEDY, S. 1999. A critical review of knowledge management models. The learning organization, 6(3):91-100.

MCELROY, M.W. 2000. Integrating complexity theory, knowledge management and organizational learning. Journal of knowledge management, 4(3):195203. 
MCMILLAN, J.H. \& SCHUMACHER, S. 2006. Research in education. evidencebased inquiry. 6th ed. Boston: Pearson.

MEWBORN, D.S. \& HUBERTY, P.D. 2004. A site-based model for professional development at the elementary school level. Pythagoras: 2-7, June.

MUNDRY, S. 2005. Changing perspectives in professional development. Science educator, 14(1):9-15.

RHODES, C. \& HOUGHTON-HILL, S. 2000. The linkage of continuing professional development and the classroom experience of pupils: barriers perceived by senior managers in some secondary schools. Journal of inservice education, 26(3):423-435.

RILEY, B. 1998. You are entering the age of the mind: thoughts on the Knowledge Society. Australian library journal, 47(2):145-156.

ROBINSON, R. \& CARRINGTON, S. 2002. Professional development for inclusive schooling. International journal of educational management. 16(5):239-247.

SMITH, E.A. 2000. Applying knowledge-enabling methods in the classroom and in the workplace. Journal of workplace learning, 12(6):236-244.

SOUTH AFRICA. 2007. National policy framework for teacher education and development in South Africa. Vol. 503, no. 29868. Pretoria: Government Printer.

SPARKS, D. \& RICHARDSON, J. 1997. A primer on professional development. Journal of staff development, 18(4):1-8.

SPECTOR, B.S. 1993. Order out of chaos: restructuring schooling to reflect society's paradigm shift. School science and mathematics, 93(1):9-19.

STRYDOM, H. \& DELPORT, C.S.L. 2005. Information collection: document study and secondary analysis. (In De Vos, A.S., Strydom, H., Fouch, C.B. \& Delport, C.S.L., eds. Research at grassroots for the social sciences and human service professions. 3rd ed. Pretoria: Van Schaik. p. 314-325.)

VAN EEKELEN, I.M., VERMUNT, J.D. \& BOSHUIZEN, H.P.A. 2006. Exploring teachers' will to learn. Teaching and teacher education, 22:408-423.

VAN NIEKERK, L.J. \& KILLEN, R. 2000. Recontextualising outcomes-based education. South African journal of higher education, 14(3):76, 90-100.

WANZARE, Z. \& WARD, K.L. 2000. Rethinking staff development in Kenya: agenda for the twenty-first century. The international journal of educational management, 14(6):1-14. Http://www.emerald-library.com/brev/06014fc1. htm Date of access: 16 Aug. 2006.

WENGER, E. 1999. Learning as social participation. Knowledge management review, 6:30-33.

WENGER, E. 2000. Communities of practice and social learning systems. Organization, 7(2):223-246. (SAGE social science collection.)

WENGER, E. 2001. Organically grown. $T+D, 55(6): 40-41$.

WENGER, E. 2007. Communities of practice: Third Annual National Qualifications Framework Colloqium. Velmore Conference Estate.

YU, H., LEITHWOOD, K. \& JANTZI, D. 2000. The effects of transformational leadership on teachers' commitment to change in Hong Kong. Journal of educational administration, 40(4):368-389. 


\section{Key concepts:}

continuing professional development of teachers

professional development

Wenger: social learning theory

\section{Kernbegrippe:}

professionele ontwikkeling

voortgesette professionele ontwikkeling vir onderwysers

Wenger: sosiale leerteorie 
